\title{
What Catholic educators can learn from the radical Christianity and Critical Pedagogy of Don Lorenzo Milani
}

\author{
Michael Grech \\ Peter Mayo \\ University of Malta
}

This is an accepted manuscript of an article published by Taylor \& Francis in International Studies in Catholic Education, 2014, Vol. 6, No. 1, 33 45, http://dx.doi.org/10.1080/19422539.2013.869952

Published online 12 February 2014, available at

http://wwww.tandfonline.com/DOI:10.1080/01425692.2013.848781

\begin{abstract}
this paper exposes some of the ideas expressed or associated with the work of don Lorenzo Milani and the School of Barbiana and discusses them in the light of the teachings of the gospels. It draws out the ramifications of these ideas for a critical education in the Christian spirit. The focus throughout is on education for social justice.

KEYWORDS Sobriety, Collectivity, Peer Tutoring, Obedience, Conscientious Objection
\end{abstract}

Contact: peter.mayo@um.edu.mt 


\section{CRITICAL EDUCATION AND RADICAL CHRISTIANITY IN THE WORK OF LORENZO MILANI}

\section{Introduction}

This paper is being written in a year which marks the 90th anniversary of the birth of one of Italy's foremost critical educators, the controversial Catholic priest, don Lorenzo Milani (1923-1967). His social activism and pedagogical insights are of relevance to a critical education which consciously connects education to power and focuses on the empowerment of the traditionally disenfranchised who are conceived of as critical social actors (not simply producers and passive consumers of knowledge or of anything else). Milani's insights anticipated or coincided with much of the spirit of Vatican Council II and, more radically, Liberation Theology.

Yet Milani was not the only educationally-committed Catholic who made an important contribution to this field. Fr Jimmy Tompkins in Canada (Lotz and Welton, 1997) and specifically in Antigonish, don José María Arizmendiarrieta in the Basque region of Mondragón in Spain, Dorothy Day of the Catholic Workers' Movement in the USA (McKinley Parrish and Taylor, 2007), don Primo Mazzolari in Italy and Frei Betto (Carlos Aberto Libânio Christo) in Brazil, to name but a few, are also Catholic figures who used education as a means to achieve social justice. Many of these figures, Milani in particular, show how the more dynamic and social justice-oriented aspects of the 
Gospels can have as much a radical effect on thought and action as can some of the most militant secular political creeds and programmes. Mario Capanna noticed this in relation to the impact of a particular work with which Lorenzo Milani is very much associated, the Lettera a Una Professoressa (Letter to a teacher) written by his students under Milani's direction. This letter greatly influenced the 1968 movement in Italy, a movement in which Capanna distinguished himself as student leader. (Capanna, 2007, civ).

\section{This paper}

In what follows we give a brief biography of Lorenzo Milani. Then we highlight some general aspects of Catholic Education and present Milani's own contribution. We argue that Milani's work constitutes a genuine effort to incarnate in this world the Good News that is contained in the Gospels (a term which itself means 'good news').

\section{Lorenzo Milani (1923-1967)}

Lorenzo Milani Comparetti was born into a very privileged family in Florence, Italy; to what is known as the alta borghesia (upper middle class). His family's wealth can be measured by the fact that they owned three houses, including one in the country and one by the sea, and by the fact that of the fifteen cars available in Florence, two were owned by Lorenzo's father (Fallaci, 1993, 13 -14). Lorenzo was driven on a daily basis to school by the family chauffeur, an aspect of his upbringing which greatly embarrassed him since he insisted on being dropped off two stops before, not to be seen being afforded luxurious treatment by his school mates. He would later react to his privileged upbringing by living and advocating austerity. ${ }^{\mathrm{i}}$

His parents were Jewish by birth but practiced no religion. They were highly educated, with his father combining various interests with a professorship at the University of Florence and his mother possessing an excellent academic education, having studied with James Joyce at Trieste. In this rich cultural milieu, university attendance was regarded as par for the course. Milani, however, chose art instead of the university, enrolling at the world-famous Brera Academy in Milan. Influenced in Florence by a German art tutor H. J. Straude, he began to explore the religious significance of works of art which, combined with other readings and feelings, pushed him in the direction of the Catholic faith, much against the grain of the family tradition. He eventually decided to embrace the sacrament of confirmation and this was followed 
by his joining a seminary. In his seminary days, Milani proved to be an intellectually challenging student, to the point of calling lecturers to task for their lack of preparation and for some statements they made which he regarded as problematic, especially one person and his statements concerning Luther. He took up Holy Orders, much to the chagrin of his mother who remained an atheist all her life and would sardonically exclaim 'bad milk' when she was once reminded by Lorenzo's wet nurse that both he and the latter's son became priests. (Fallaci, 1993, 27)

Milani's first significant pastoral experience was at San Donato di Calenzano, a hilly district in Tuscany, where he came in close contact with the hard life of peasants and industrial workers. Milani began to understand the extent of their exploitation, and realised even further how standard curricula in Seminaries did not equip priests with the intellectual and human tools necessary to understand and fruitfully engage with realities of this kind. At San Donato he helped develop an adult and youth education programme in the evening school (scuola serale) set up by his Parish Priest, don Daniele Pugi.

Milani's experience at San Donato coincided with a period of extreme tension between the Vatican and its political allies (primarily the Christian Democratic Party) on the one hand, and the Left (primarily the Communist and Socialist parties) on the other. Many in the Catholic Church feared that success by the Left at the polls would pave the way for a Communist take-over in Italy. The Catholic Church hence mobilised all its forces, parishes and clergy in particular, to prevent this possibility. The Vatican wanted to present Catholics who harboured left-wing sympathies with a stark choice; you either choose your party or your Church.

Within this political context, Milani took the radical step of removing all religious symbols from his school (including the crucifix), in order to render the place as nonconfessional and a-political as possible. The educational activities at San Donato included drama and social debates, but not compulsory Catechism classes. Milani vehemently criticised the standard ways in which Catechism was taught in his day. He personally felt that accepting the Catholic faith is a grace of God. Hence the Catholic faith is something which cannot be forced upon or 'traded': I teach you to read and write, but you attend Catechism and become a good Christian. 
His activities and approach irritated the most conservative sectors of his parish, and landed him in hot water with ecclesiastical authorities. He was removed from the locality and posted to (read: sent 'into exile' at) the forlorn mountain site of Sant'Andrea a Barbiana, much to the anger and consternation of the community.

On the day he received the news, he 'smashed the sacristy' ${ }^{\text {ii }}$, but then accepted his transfer, not only out of obedience to the Church's authorities, especially the Archbishop, but also because he believed that this was his fate as part of God's 'grand design. iii $\mathrm{He}$ would claim that no one has the right to take the brush from the Grand Artist's hand and add a detail of one's own. He felt that God wanted him at Barbiana and that he had no right to alter his Creator's 'grand design.' Indeed, one of the first things Milani did at Barbiana was to purchase a grave so as to cement his presence in the new environs. He also resisted attempts by his mother to have him removed, through her contacts, from the locality.

Barbiana was not even a village. The Church and the priory (which Milani would turn into a school) were isolated from the sparse farmhouses which existed in the region. These were inhabited by peasants who not merely had no contact with the world, but even felt shame and fear on the rare occasions when they met some city dweller. Rather than being subdued by this apparent isolation, Milani opened a school and developed a radical pedagogy with the children of this socially-marginalised group. Most of them not only gradually mustered literacy, mathematics and instruction in the sciences, but were later to contribute to trade unions, political parties and education. Above everything, they learned and taught others to think critically. A non-dogmatic reading of the Gospels provided sources of reflection, together with the analyses of newspapers as well as readings from a variety of texts from literature, history (e.g. Gandhi’s biography) and politics (including texts by Gramsci ${ }^{\mathrm{iv}}$ ), amongst others.

Milani's work attracted the media and the general public's attention. Yet, he always ensured that the school would not dance to the tune of mainstream media and opinion. Milani's students were known to grill rather than court the many journalists and public figures who visited the place.

At Barbiana, Milani wrote his Esperienze Pastorali (Pastoral Experiences), which focused on his experience at San Donato. The book was denounced by many 
Catholic authorities, including Angelo Roncalli, then Bishop of Venice, later to become Pope John XXIII. With his students, he wrote letters in defence of the right to conscientious objection. Alas, his life was short since he contracted and eventually succumbed to Hodgkin's decease at the age of 44, however not before directing, partly from his deathbed, a work which was to become a masterpiece of critical educational narrative. This is Lettera a Una Professoressa (Letter to a Teacher, henceforth the Lettera).

\section{Catholic Education.}

Teaching lies at the heart of the Church's mission. One of the fundamental aspects of Christ's mission on earth is His teaching. Teaching is one of the main ministries which Christ entrusted to the church, a ministry addressed to all humans. The teaching in question concerns Jesus Christ's good news: His announcement of God's kingdom. Special ministers were charged with this function. This, in turn, necessitated that these ministers are provided with special instruction to enhance their teaching abilities. They had to be able not merely to announce the Good News, but to interpret it in light of daily exigencies, understand the meanings and connotations of Christ's work and defend the genuineness of the Gospel. In time, and owing to specific and concrete cultural, social, economic and political circumstances, the church was led to venture in such fields as Theology and Philosophy. Later on, the Church was to dominate (at least in Europe, particularly in the 'theocentric world' of the Middle Ages) these fields and the way they were taught, not least in those hallowed places called universities.

In the modern period, particularly in the nineteenth century, the Catholic Church started providing education on a broad scale through schools. This education was not limited only to adults and to those who were pursuing a priestly formation. These schools were generally intent not merely on educating students, from a young age, in a variety of subjects but also on promoting Catholic mores and values, and in forming students accordingly. The history of these Catholic schools is extremely diverse and chequered (Grace and O'Keefe, 2007). Yet, in such countries as Italy and Malta, these schools enrolled students against the payment of a specific fee ( Gozzer, 1964) and some gained a reputation of excellence and distinction (see Mifsud, 1997, 236). This reputation inevitably led these schools to be implicitly considered as out-of-reach of certain 
categories of students, including those whose parents could not afford to pay these fees (see Darmanin, 1993, 157) and those who failed to excel in academic performance. In both Italy and Malta however, the church also exercised a role in public education, especially after the so-called 'second concordat' in Italy (involving the Craxi government - Holy See, 1985) and more recent moves in Malta where around 32\% of children (excluding kindergarten and postsecondary education) ${ }^{\mathrm{v}}$ are now being educated in Church schools as a result of government funding. In public education the teaching of the Catholic religion (through teachers who require the local Curia's approval) is guaranteed (see Borg and Mayo, 2006, 49). Moreover, the Church's influence in public schooling is felt to extend beyond the teaching of Catholic religion.

So, broadly speaking, the Italian Catholic church, in Milani's day, provided three types of teaching:

1. Pastoral teaching (sermons, catechism, etc.) which were provided freely to all Catholics.

2. Catholic schools that generally catered for students who came from a certain economic/cultural background, could pay certain fees and excelled academically 3. Catholic universities.

Additionally, the Catholic church also had a say on what was taught in public schools. Many Catholics were satisfied with this arrangement. They thought this kind involvement generally satisfied the Church's teaching ministry as entrusted to Her by Jesus Christ. Apparently, Milani was not one of these Catholics.

We will now discuss his pedagogical initiatives that are subsequently assessed in the light of the Gospels' spirit and teachings. ${ }^{\text {vi }}$ Each section focuses on one paticular aspect of Milani's pedagogy and work, and assesses it in light of the Good News. The relevant aspects are i) Milani's option for the poor; ii) their empowerment; iii) the consideration of knowledge as a heritage belonging to the entire community iv) the community as comprising individuals with different gifts v) the duty to disobey.

\section{Radical Christianity - The preferential option for the poor}

A radical interpretation of the Gospels lies at the heart of Milani's thinking and pedagogical approach. According to his reading, the Gospels fore-grounded an option for 
the oppressed- 'gli ultimi' (the least positioned socially), in Italian - a phrase which features prominently in the title of one of his best biographies (Fallaci, 1993). This is very much in line with the very nature of the Gospel itself. While the Good News is announced to all people, it resonates particularly with the poor and their plight. The rich are many times rebuked ("Do not store up for yourselves treasures on earth, where moths and vermin destroy, and where thieves break in and steal." Matthew 6:20) and warned that their riches obstructed their entry into the kingdom. ("How hardly shall they that have riches enter into the kingdom of God! ... It is easier for a camel to go through the eye of a needle, than for a rich man to enter into the kingdom of God." Mark 10: 24-25). This attitude towards the rich was adopted by Christ's closest disciples ("You have lived on earth in luxury and self-indulgence. You have fattened yourselves in the day of slaughter." James 5: 5).

The very first recorded announcement of the Good News was made by Christ in his home town synagogue (Luke 4: $14-18$ ), and was specifically addressed to the outcasts and oppressed. Quoting Isiah, Christ proclaims that he came "To preach the gospel to the poor...To set at liberty those who are oppressed: To proclaim the acceptable year of the Lord." (Luke 4: 18). In 1967, Gustavo Gutierrez coined the phrase 'preferential option for the poor' (1973). Catholic schools in Italy however, continued to treat all children 'equally'. They paid no heed to economic and cultural differences, and failed to privilege those who had less ahead of those who had more. They actually maintained cultural and economic glass-barriers which prevent the poor, save perhaps for a few token exceptions, from enrolling in its educational institutions. Milani took the opposite course. His choice between the haves and the oppressed was made first at San Donato and later at Barbiana through his schools. He argued for "the right to divide the world into disinherited and oppressed on one side, and privileged and oppressors on the other. One group is my Fatherland; to me the others are foreigners" (Milani, 1988a, 19)

Milani was aware of the huge strides which the socially excluded had to make to attain that which came almost naturally to him and other members of the bourgeoisie by virtue of their materially rewarding cultural capital. He relentlessly seemed to have pursued something on the lines of Tanzania's slogan in the late $60 \mathrm{~s}$ and $70 \mathrm{~s}$, 'we must run while others walk'. His education, therefore, could not cater equally for the rich and 
poor. The Giannis (the term in the Lettera for the have-nots, the children of peasants and workers) were as welcome as, and, if anything, were more important than, the Pierinos, the latter being the 'figli di papà' (daddy's children) who, because of their materially rewarding bourgeois cultural capital, monopolised all positions of power purportedly said to be distributed on 'merit.' As stated by his students who wrote the Lettera, "there is nothing as unjust as trying to create equality among those who are not equal." (School of Barbiana, in Borg, Cardona and Caruana, 2009, 155).

...whoever lacked the basics, who was slow or unmotivated, felt that he was the favourite one. He was welcomed just as you'd welcome the first in class. It seemed as if the school existed solely for him. Until he understood, the others did not move ahead. (Borg, Cardona and Caruana, 2009, 36)

For Milani, a genuinely Christian inspired education was one in favour of the 'meek' who 'shall inherit the earth'. (Matthew 5: 5) Education was identified as one of the needs of the poor and powerless in a quest for them to become 'sovereign citizens' ("cittadini sovrani”), exercising their right to govern. This aspect points to another feature of Milani's educational project. This is the need to make students from socially-deprived backgrounds aware of the rights which were being denied them and promote their empowerment in their quest for 'bread and dignity.'

\section{Empowerment}

When, moved by the Spirit, Jesus Christ made his first announcement of the Good News. He proclaimed that he was sent "to heal the broken-hearted. To proclaim liberty to the captives. And recovery of sight to the blind." (Luke 4: 18). His message then had three aims: 1) to comfort and heal; 2) to free 3 ) to make the blind see. The blindness in question need not just be physical. It may involve the failure to be aware of one's potential, something that can constitute an obstacle's to one's freedom and prevent one from healing oneself. The Good News then is not for passive listeners. It is for people who are transformed, who acquire the ability to see and become free. This seems to require a 'bottom up approach' in which members of a subaltern class or group - those who are blind and not free - would acquire the confidence and ability to see and release themselves from their shackles. 
Milani's school and its pedagogy reflect this fundamental insight. They upheld an education intended to provide a sense of leadership from below, as in certain pastoral centres in present day Brazil (Betto, in Borg and Mayo, 2007, 35-36). Amongst other things, students were encouraged to concretely adapt what they learnt, interacting with other people and standing up for themselves and their rights (see, for instance, Gesualdi, 2008). This empowerment was later reflected in the militancy of some former students in trade unions, political parties and social movements. At Barbiana, they acquired the necessary skills and developed the relevant attitude to lead (in concert with others), and to become what Gramsci would call 'organic intellectuals.'

Once again, this contrasted with the staple of certain Catholic schools in Italy (and in our own country) at the time, given their virtual option for children from a privileged or at least relatively well-off background. When confronted with the unfairness of this situation, many within these institutions tried to justify their top-down modus operandi by claiming that they also were helping by indirectly changing the status quo. There were instances when they sought to do this by moulding tomorrow's leaders who, in turn, would change society according to the Church's mores and the Catholic conception of social justice (Mifsud, 1997, 345). In many cases, however, these schools empowered those who were already powerful. This however represented not the only point of divergence with Milani's pedagogy. One other difference concerned the question of knowledge ownership.

\section{Knowledge as common heritage}

One official reason behind the Catholic schools' charging of fees was economic sustainability. Irrespective of its validity or otherwise, this situation frequently led not merely to the exclusion of those who could not pay, but also to the commodification of knowledge. Knowledge becomes a commodity which persons can purchase if they possess the wherewithal to do so. In an era when competitiveness is rife, the knowledge one purchases enables one to hold the edge over one's competitors. Knowledge acquisition becomes a positional good. This arrangement frequently leads to situations 
when Christ's instruction, "Freely you have received; freely give" (Matthew 10: 18), is completely ignored.

On the other hand, Milani's school not only provided learning free of charge but promoted the kind of education which imparts knowledge not for personal possession and gratification but for being of service to others. It was an education that responds to that higher 'calling' for persons to care and use the acquired knowledge to help develop (not alone, but with others) a better and more socially just world.

An English motto was chosen for the School of Barbiana: 'I Care'. For Milani, this meant caring about everything and everyone (this attitude recalls, albeit in a secular and worldly context, the mystic injunction to see God in everything and everything in God). ${ }^{\text {vii }}$ Alas possessing knowledge as a symbol of distinction has become a mantra in this neoliberal governed world, given to turning everything including education into a consumption good. The Barbiana school's alternative philosophy required a 'caring' educational relationship based on not 'having' (possessive knowledge and individualism) but 'being' and 'being' for others. Avarice, one of the Seven Deadly Sins highlighted during the Middle Ages, is ever present, incorporating all sorts of perceived positional goods, including education. It had to be confronted and resisted.

It also had to be confronted by a particular lifestyle. Sobriety was one of the virtues Milani sought to impart, a virtue he sought to promote by example, being wary not to exceed the lifestyle of his poor parishioners - perhaps a reaction to his prosperous past, as some of his fellow seminarians argued. Indeed, on his dying bed, he was hard on himself, visibly in tears for having been too austere with his students but then he pulled himself together with the important warning that excessive consumerism knew no bounds and would spiral out of control (Martinelli, 2007). This would suggest that his preference for austerity and sobriety did not arise simply out of some guilt-feeling for his previously privileged lifestyle, but was also a tool which could enable his students not to be lulled by a false sense of prosperity that is typical of the consumerist society which Italy was becoming in the $60 \mathrm{~s}$.

This anti-consumerist approach stands in good stead not only the Catholic educator, in an attempt to thwart Mammon, but any educator conscious of the prevalent politico-economic ideology of the present times which converts one time social and 
public goods into sources of consumption. Indeed, his ideas in this regard were shared by Pier Paolo Pasolini, one of Italy's intellectual icons. Additionally, as the letter to Pipetta (a young Communist partisan from Prato) demonstrates, Milani’s shunning of earthly goods was in keeping with his preference for 'God's bread' (Milani, 2007b, 22), a spiritual aspect of his life that is frequently ignored by many of his secular admirers. ${ }^{\text {vii }}$

The collective dimension of knowledge was reflected in the way the educational process developed at Barbiana. The 'I Care' motto, and the collective dimension of learning it entailed, translated into many remarkable forms of practice. For instance, the class was not to move to the next stage of learning until all pupils mastered the present one. Milani's school rejected an educational process based on failure and casting of people aside. This was in sharp contrast to the public school system likened, in the Lettera, to a hospital that treats the healthy and rejects the sick. On the contrary, the Barbiana School, true to its basic Christian and genuinely democratic ideals, attempted to bring everyone on board in this educational journey.

Catholic schools in Italy, unfortunately, were not immune to becoming institutions of exclusion favouring some at the expense of others. Even in our day, we come across Catholic schools, at least in our own country, that get caught up in the contemporary globalised rat race in which achievements are measured in restricted terms. One would think that these schools would have much to learn from the Barbiana experience.

The social class-based culture of competitive individualism, predicated on a 'profane', secular capitalist ethic, was alive and well in Milani's time. Milani would have no time for elitist Catholic schools who would use prize day ceremonies to indulge in speeches indicating how competitively successful their students were in sweeping all before them. They said 'No' to this kind of pressure. Milani's school, therefore, had a strongly communitarian ethos. This dimension, however, did not stifle individuality.

\section{Different gifts}

"God has appointed in the church first apostles, second prophets, third teachers; then deeds of power, then gifts of healing, forms of assistance, forms of leadership, various kinds of tongues. Are all apostles? Are all prophets? Are all teachers? Do all work miracles? Do all possess gifts of healing? Do all speak in tongues? Do all interpret?" (1 
Corinthians 12:28-30) From its inception, therefore, the Church was a community of different individuals with different gifts; gifts which these individuals would place at the service of the community. The Church implicitly accepted the ideal of unity in difference. The dichotomy between individuality and community simply did not exist.

Milani's schools, though not consisting of prophets, apostles and miracle workers, echoed the structure of this basic Christian community. Milani's students did not have the same abilities, not least because they belonged to different age-groups. Difference however was not shunned but recognised and addressed concretely. The different ageconditioned abilities of some and the acquisitions of all were used for the benefit of communal goals and purposes, rather than to enable individuals to carve out a position exclusively for themselves.

Students studied in groups. Use was made of peer tutoring for various reasons, not least logistical reasons. The Lettera sheds light on the scarcity of material resources at Barbiana:

There was only one copy of each book. The boys used to crowd around it. It was hard to notice that one was a bit older and was teaching. The oldest of those teachers was sixteen years old. The youngest was twelve and I was full of admiration for him. I decided from the first day that even I would teach."(Borg, Cardona and Caruana, 2009, 36)

Milani himself tutored the first group of students. The older students, while learning from Milani and other students of more or less the same age, taught the younger ones: "The following year I was a teacher. That is, I was a teacher for three half-days a week. I taught Geography, Mathematics and French to the prima media class (Ibid, 37)" This must have helped the student-teachers learn the material better since they enhanced their own understanding of what was learnt through the effort involved and various avenues explored in conveying it to others. Moreover, it must have served as a tremendous source of motivation for the students, once degraded and therefore demoralised by the public schools, to now be 'elevated' to the status of and esteemed as teachers. It is hardly surprising that they would prefer these experiences to the messy ones encountered in the fields: "school will always be better than shit." (Ibid, 36). 
This unity in difference was arguably best reflected in the School of Barbiana's public pronouncements. In the compiling of the 'Letter to the Military Chaplains' and 'The Letter to the teachers', Milani's students were encouraged to place all their individual random ideas on sheets of papers. A systematic ordering and sifting through then occurred through collective discussion until some key non repetitive ideas remained which allowed for a coherent piece of writing. They eliminated superfluous words, redundancies, overly long sentences and made sure not to have more than one concept in a single sentence. Individuality and a community-oriented approach are splendidly blended. (Borg, Cardona, Caruana, 2009, 139). As one student recalled:

At Barbiana I had learnt that the rules of writing are: to have something important to say and that it may be useful to everybody or to many. To know who you are writing to. To gather all that is necessary. To find a logical way of putting it in order. To eliminate any unnecessary word. To eliminate any word which we do not use while speaking. Not to set any limits of time. (Ibid, 44)

Collective writing served a purpose; the purpose of learning with and acting on one's learning with others. But arguably Milani's and his school's greatest contribution to genuine individualism was the promotion of the virtue of disobedience with regard to militarism.

\section{The duty to say: No!}

In Milani's day, many within the Catholic Church considered obedience to authority a fundamental, if not the most fundamental, virtue. Nationalist discourse extended this insight to the state; citizens are duty-bound to obey their legitimate authority for the greater good of the Homeland. In the 20s and 30s, Fascism made obedience one of its slogans. Even in post-Fascist Italy, this approach persisted to a certain extent. It was particularly evident in the armed forces. Interestingly, this emphasis on obedience is markedly absent from the Gospel. The Good News was to be freely accepted and, once it was accepted, one had to be obedient to the Gospel. Followers of Christ have: "The glorious liberty of the children of God" (Romans 8:21). In the words of Paul, it is those who disobey the gospel, and not those who defy worldly powers, "who shall be punished with everlasting destruction from the presence of the Lord, and from the glory of his power." (II Thessalonians 1:7-9) 
At his school in Barbiana, Milani did not simply seek to foster his students' individual talents. He sought to help them develop their character and to instill in them the desire to advocate and take action on a variety of issues. He wanted to help form individuals capable of standing on their feet and saying 'No!'

This is arguably best revealed in the 'Lettter to the Military Chaplains'. Here, the school of Barbiana affirmed the right to a conscientious objection to military conscription. The arguments in the letter are inspired by two documents in particular, namely the Italian Constitution and the Gospels. In the letter, Milani and his school frequently refer to a basic tenet of Christianity, namely a commitment to peace and nonviolence. They could easily have cited the Christian value of Liberty mentioned by the Apostle Paul.

Further importance of the letter lies in the emphasis it places on the duty to say no in certain situations; it underlined that, contrary to what was taught in some Catholic Conservative circles, obedience is not always a virtue (the title of the Italian version of this letter and the one addressed to the judges: L-Obbedienza Non è Più Una Virtù). From the Christian standpoint, this stand is valid on two counts. It reconnects with the old Christian ideal of standing for the Good News regardless of the repercussions. In these moments, Catholics are called upon to 'speak truth to power'. It is this attitude which led to countless Christian martyrs shedding their blood and testifying their faith through their ultimate sacrifice. Secondly, it warned Catholics and Christians against the dangers of falling prey to nationalistic and chauvinist discourse. Selfish imperialist interests were advanced under a Christian guise. Milani rightly associated this attitude with Fascism. He recalls how, as a pupil, he "jumped with joy for the empire" when the Italian troops invaded a blameless Ethiopia, using outlawed chemical weapons (Milani, 1988, 65).

The defence of the right to a conscientious objection referred to an article centring on a military chaplains' convention (this convention denounced conscientious objection) which appeared in the Tuscan paper La Nazione. Newspapers were important sources of learning at the School of Barbiana. Together with other material, they kept the Barbiana students rooted in the world which had to be read, in Freire's terms, alongside the word (Freire and Macedo, 1987). The Barbiana students, however, did more than this. They collectively discussed the issues raised in the newspaper and often collectively wrote 
back to the Editor. One such letter was the 'Letter to the Military Chaplains'. This was published in the Communist review Rinascita, the only review to afford them space to do so. Being a Christian in the world entailed not only 'reading the word and the world' but also 'writing the word and the world' (Taylor, 1993). ${ }^{\text {ix }}$

Milani’s warning against Christians falling prey to a jingoistic military discourse is still relevant today as we are facing a massive culture of militarization, emerging primarily from the USA. This culture is couched in terms of 'exporting democracy' and the 'war on terror'. These have unfortunately become code words for attacks on defenceless people such as the citizens of Iraq (they recall Italy's imperial attacks on Ethiopia), trading blood for oil, and having a carte blanche to impinge on civil liberties (including migrants' right to asylum) on the grounds of 'security'. Even today, obedience may not always be a virtue. Christians are also called to give testimony by their noncompliance.

\section{Conclusion}

There is much grist for the mill of a radical Christian education in the ideas and work of don Lorenzo Milani and his students. We would argue that there is grist for the mill of an educational approach which serves as an antidote to the current Neoliberal mantra of marketability, entrepreneurship, technical rationality and excessive competitive individualism and which would appeal to critical educators in general, irrespective of whether they belong to any religious denomination or not. His work has been well received in various circles not least sociology of education and critical education circles, ${ }^{\mathrm{x}}$ just as they served as manifestos for the 68 movement in Italy which embraced atheists, agnostics and left wing Catholics at the same time.

Milani's special appeal to the 'Cattolici di Sinistra' (Catholics on the Left) movement in Italy, however, also indicates that the radically Christian tenets of his philosophy and educational approach, as well as his social vision, cannot be overlooked as they often are, at times conveniently so. As with Liberation Theology and the Prophetic Church, there is a reinvigorating emancipatory potential in this approach that takes Christianity to its roots. It calls for a pedagogy (viewed in its broadest sense) of the oppressed and of love that entails communal sharing and political empowerment. In its sobriety and preferential option for the poor and powerless, it takes into account the 
totalizing structures of oppression and the way mainstream schooling is often embedded in them. The Barbiana pedagogy emerges from a 'school in the world' which regards learning and knowledge as everyone's entitlements and therefore as public goods. This pedagogy has a key collective dimension. The knowledge and learning it promotes belongs to not the world of 'having' but the world of 'being' - knowledge placed at the service of humanity and other species for the creation of that better world that is possible.

\section{Notes}

\footnotetext{
${ }^{\mathrm{i}}$ Milani was later to distinguish himself for his austerity both as a Seminarian and as a diocesan priest.

ii Speciale TG1 (Rai - Italian State Broadcasting Station Channel 1) http://www.youtube.com/watch?v=p_KJuVkZC2w Accessed $3^{\text {rd }}$ November 2013.

${ }_{\text {iii }}$ He felt that God spoke to him through his conscience (Corzo, 2011). Parallels were drawn with Socrates in this regard (Formazione e Ricerca Don Milani e Scuola di Barbiana, 2008, p. 36). This spurred Milani into action, often against the status quo, before the usual admonition by the Archbishop who would order him to stop. Milani would acquiesce. (Gesualdi, 2011, 12)

${ }^{\text {iv }}$ Milani had an ambivalent attitude towards socialism in general and towards the Italian Communist Party (the largest in Western Europe) in particular. In his 'Letter to the Judges', he calls 'socialism' the "highest attempt of humankind to give, already on this earth, justice and equality to the poor." (Milani, 1988a, 26). In a 1950 letter to Pipetta, Milani declared that he shared with communists the struggle to combat the subjugation and abuse of the oppressed and redress the various injustices they suffer. (Guzzo, 1998, 123) Yet, he claimed that he would have parted company with the party the moment these goals were reached. (Guzzo, 1998, 123) Moreover, he frequently took the Communist Party and the Catholic Church to task for vying with each other to win over youngsters by what he regarded as frivolous activities such as dances and football rather than investing in a broad education.

${ }^{v}$ We are indebted to Professor Mary Darmanin of the University of Malta, who has researched Catholic education (see Darmanin, 2013), for the accuracy of this statistic.

${ }^{\text {vi }}$ Quotes will be taken from the The New King James Version 1990 New York 1990 American Bible Society.

vii There are enough indications by now to make the reader realise that this was not merely a contemplative school, based on the medieval model of the contemplative life, but very much a school in and not simply for the world, a concept which coincided with the notion of a Church not for but in the world.

${ }^{\text {viii }}$ We thank Joseph Bezzina for this insight.

${ }^{\text {ix }}$ This approach was to be repeated in the classic text, Lettera a una Professoressa, whose official authors are eight boys from the school, and which focused not only on the Italian public school system but, in the words of the Pasolini, on Italian society at large. My translation from the original in Italian. http://www.chille.it/progetti-in-corso/progetto-don-milani-lettera-a-una-professoressa/ Accessed $3^{\text {rd }}$ November, 2013.
}

${ }^{\mathrm{x}}$ The Lettera was used as a set text in a critical sociology of education Open University course in the 70s Dale, 2014

\section{References}


Borg, Carmel and Peter Mayo. 2006. Learning and Social Difference. Challenges for Public Education and Critical Pedagogy, Boulder and London: Paradigm

Borg, Carmel and Peter Mayo. 2007. Public Intellectuals. Radical Democracy and Social Movements. A Book of Interviews, New York: Peter Lang.

Borg, Carmel, Mario Cardona and Sandro Caruana (2009), Letter to a Teacher. Lorenzo Milani's Contribution to Critical Citizenship, Malta: Agenda.

Capanna, Mario. 2007. 'Una 'Lettera' al Futuro' (A Letter for the Future). In Scuola di Barbiana. Lettera a Una Professoressa. Quarnt' anni dopo (School of Barbiana. Letter toa Teacher. 40 years Later), edited by Michele Gesualdi, CIII-CV, Florence: Libreria Editrice Fiorentina.

Centro Formazione e Ricerca Don Lorenzo Milani e Scuola di Barbiana (2008) Socrate e Don Lorenzo (Socrates and Don Lorenzo), Vicchio, Florence: Centro Formazione e Ricerca Don Lorenzo Milani e Scuola di Barbiana.

Corzo, José L. 2011. "Alla Scuola della Parola. Analisi teologico-spirituale degli scritti di don Lorenzo Milani" (For the School of the Word. A theological-spiritual analysis of Lorenzo Milani's writings). In Don Lorenzo Milani e la Scuola della Parola. Analisi storica e prospettive pedagogiche (Don Lorenzo Milani and the School of the Word. Historical Analysis and Pedagogical Perspectives), edited by Roberto Sani and Domenico Simeone, 233-246, Macerata: Edizioni Università di Macerata (eum).

Dale, Roger. 2014. "Preface" In Lorenzo Milani, the School of Barbiana and the Struggle for Social Justice, by Federico Batini, Peter Mayo and Alessio Surian, VII-IX, New York: Peter Lang.

Darmanin, Mary. 1993 "More things in heaven and earth: contradiction and co-optation in education policy', International Studies in Sociology of Education, 1 3(2):147-172

Darmanin, Mary. 2013. "The material and symbolic cultures of the everyday-religion in Maltese primary schools." In Religious Education in Multicultural Europe: Children, Parents and Schools, edited by Emer Smyth, Maureen Lyons and Merick Darmody, 69100, Basingstoke: Palgrave Macmillan.

Fallaci, Neera. 1993. Vita del Prete Lorenzo Milani. Dalla parte dell'ultimo (Life of the Priest Lorenzo Milani. On the side of those who are the socially least positioned), Milan: Biblioteca Universale Rizzoli.

Freire, Paulo and Donaldo Macedo.1987. Literacy: Reading the Word and the World, Massachusetts: Bergin \& Garvey. 
Gesualdi, Michele. ed. 2008, Il Ponte di Luciano a Barbiana (Luciano's Bridge at Barbiana), Florence: Libreria Editrice Fiorentina.

Gesualdi, Michele 2011 “L'obbedienza di don Lorenzo.”(don Lorenzo's Obedience) In L'obbedienza nella Chiesa (Obedience in the Church), by Lorenzo Milani, 7-29, Florence: Liberia Editrice Fiorentina.

Gozzer, Giovanni. 1964. I cattolici e la scuola (Catholics and the School), Florence: Vallecchi Editore

Grace, Gerald and Joseph O'Keefe. eds. 2007. International Handbook of Catholic Education Challenges for School Systems in the 21st Century (2 vols.), Dordrecht: Springer.

Gutierrez, Gustavo 1973. A Theology of Liberation, Maryknoll, NY: Orbis Books.

Guzzo, Giuseppe 1998. Don Lorenzo Milani, un rivoluzionario, un santo, un profeta, un uomo (Don Lorenzo Milani, a revolutionary, a saint, a prophet, a man), Soveria Mannelli (Catanzaro): Rubbettino Editore.

Holy See (1985) “Accordo tra la Santa Sede e la Repubblica Italiana che apporta Modificazioni al Concordato Lateranense"(Agreement betwen the Holy See and the Italian Republic that provides Modifications to the Lateran Concordat) http://www.vatican.va/roman_curia/secretariat_state/archivio/documents/rc_segst_19850603_santa-sede-italia_it.html Accessed 5th November 2013.

Lotz, Jim and Michael R. Welton. 1997. Father Jimmy: Life and Times of Father Jimmy Tompkins, Wreck Cove: Breton Books.

Martinelli, Edoardo 2007, Don Lorenzo Milani. Dall'motivo occasionale al motivo profondo. (Don Lorenzo Milani. From the occasional motive to the profound motive) Florence: Società Editrice Fiorentina.

McKinley Parrish, Marilyn and Edward.W. Taylor. 2007. "Seeking Authenticity: Women and Learning in the Catholic Worker Movement" Adult Education Quarterly, 57 (3): 221-247

Mifsud, Immanuel. 1997. "The Brightest and the Best. Reproducing Elites in a Maltese School". In Inside/Outside Schools. Towards a Critical Sociology of Education in Malta, edted by Ronald G. Sultana, 335-352, Malta: PEG Publications.

Milani, Lorenzo 1988a. "Letter of Don Lorenzo Milani to the Military Chaplains of Tuscany Who Signed the Communiqué of 11 February 1965." In A Just War no Longer Exists. The Teaching and Trial of Don Lorenzo Milani, edited and translated by James T. Burtchaell, 18-28, Indiana: University of Notre Dame Press. 
Milani Lorenzo 1988b. "Milani's Letter to the Judges." In A Just War No Longer Exists. The Teaching and Trial of Don Lorenzo Milani, In A Just War no Longer Exists. The Teaching and Trial of Don Lorenzo Milani, edited and translated by James T. Burtchaell, 52-77, Indiana: University of Notre Dame Press.

Milani, Lorenzo 2007. Lettere di don Lorenzo Milani, Priore di Barbiana (Letters by Don Lorenzo Milani, Prior of Barbiana), edited by Michele Gesualdi, Cinisello, Balsamo: San Paolo.

Taylor, Paul V. 1993. The Texts of Paulo Freire, Buckinghamshire: Open University Press. 